\title{
IMPACT OF LIQUIDITY AND PROFITABILITY ON USE OF DEBT FINANCE SOURCES OF COMPANIES IN MANUFACTURING INDUSTRY IN V4 COUNTRIES
}

\author{
[Vliv likvidity a rentability na využití zdrojů financování ve zpracovatelských \\ podnicích v zemích V4]
}

\author{
Petra Růčková ${ }^{1}$ \\ ${ }^{I}$ Slezská univerzita, Obchodně podnikatelská fakulta, Univerzitní nám. 1934/3, 73340 Karviná \\ Email:ruckova@opf.slu.cz
}

\begin{abstract}
Abstrakt: The analysis of influence of liquidity and profitability on the use of debt financing sources is the object of this research. Exploring just these dependencies is based on the idea as far as debt resources must have positive impact on the functioning of companies, it must obtain the best possible conditions. Whereas acquisition of financial sources in the V4 countries is primarily focused on the banking sector, it is expected that companies, whose profitability is an increasing tendency in time and whose liquidity is stable, respectively growing, provide loans under the best conditions. This statement would thus confirm the results of the trade-off theory of capital structure. The aims of this article is finding answer to question whether there is a positive functional relationship between the independent variables (liquidity and profitability) and the dependent variable (using debt sources) in the manufacturing companies in the Visegrad group's countries of during 2006 and 2013 years.
\end{abstract}

Keywords: correlation, debt financing resource, liquidity, panel regresion, profitability.

JEL classification: G32

Doručeno redakci: 23.10.2015; Recenzováno: 27.10.2015; 4.11.2015; Schváleno k publikování: 15.12.2015

\section{Úvod}

Ústřední myšlenkou diskuse, která se vede zejména mezi akademickými pracovníky, je vliv nastavení způsobů financování na velikost generovaného zisku a také zda řízení kapitálové struktury může vést $k$ odchýlení od optimálního cíle společnosti. Tady lze totiž nalézt základní cílový konflikt. Za určitých okolností může být využití cizích zdrojů financování levnější než využití zdrojů vlastních, ale zároveň větší využití dluhu zvyšuje účinnost daňového štítu, tím však také vede $\mathrm{k}$ snížení účetně vykázaného výsledku hospodaření. Řízení kapitálové struktury závisí především na současné hodnotě přínosů a nákladů dluhového financování. V rámci této diskuse je tak potřeba hledat vliv různých faktorů na míru využití cizích zdrojů financování. Tento článek je zaměřen na vliv dvou základních faktorů likvidity a rentability. Tyto dva faktory jsou zvoleny $\mathrm{s}$ ohledem na dva základní cíle $\mathrm{k}$ podnikatelské činnosti podniků. Podnik by měly směřovat $\mathrm{k}$ rostoucí efektivitě podnikatelské činnosti. Mimo to by se podniky měly zaměřit na dlouhodobé zachování platební schopnosti, které je možné pouze při stabilizované likviditě společnosti.

Likvidita má bezprostř̌ední návaznost na využití cizích zdrojů financování. Vzájemný vztah mezi likviditou společnosti a optimálním pákovým efektem, tedy využitím zdrojů financování, je předmětem studií už mnoho let. Likvidita je vnímána jako aspekt, který umožňuje lépe se chopit př́ležitostí u neočekávaných investic, respektive umožňuje společnostem lépe přečkat nepř́znivé obchodní a ekonomické podmínky. Williamson (1988) a Shleifer a Vishny (2001) ve svých studiích tvrdí, že existuje pozitivní vztah mezi likviditou společnosti a využitím dluhu. Naopak Morellec (2001) a Myers a Rajan (1998) tvrdí, že vztah je postaven jako negativní. Pozitivní vztah je vysvětlován myšlenkou, že vysoce likvidní 
aktiva jsou z pozice nákladů finanční tísně vnímána jako méně efektivní, nebot' jejich prodej (vyjma peněžních prostředků) bývá realizován se ztrátou (hovoříme zejména o pohledávkách a zásobách). Avšak nižší hodnota likvidních aktiv zvyšuje riziko neposkytnutí finančních prostředků. Chce-li manažer zvyšovat hodnotu dluhu za výhodných podmínek, musí jej mít kryt dostatečným objemem likvidních aktiv.

Morellec (2001) se domnívá, že likvidita aktiv (tedy schopnost zapojit je do odprodeje majetku při likvidaci) snižuje hodnotu firmy a tím i její dluhovou kapacitu. Tvrdí také, že neúměrná likvidnost aktiv v podniku vede $\mathrm{k}$ nedostatečným investicím a problematickému rozvoji podniku. Oproti tomu však Kim, Mauer a Sherman (1998) ve své studii tvrdí, že dostatečná likvidita ex-ante pečuje o dostupnost finančních prostředků v budoucnosti $\mathrm{v}$ prípadě realizace investic. Zkoumali tento vztah na amerických průmyslových společnostech v letech 1975 - 1995. Podle jejich studie byl potvrzen pozitivní vztah mezi růstem investičních př́ležitostí a likviditou. Zároveň však také zjistili, že existuje negativní vztah mezi zadlužeností, resp. s jejím růstem, a likviditou.

Opler, Pinkowitz, Stulz a Williamson (1999) provedli empirickou analýzu rovněž na vzorku amerických nefinančních společností, avšak v delším časovém horizontu od roku 1952 do roku 1994. Došli ke stejnému zjištění ohledně vztahu k růstovým př́ležitostem, nicméně potvrdili také závěr Williamsonovy studie (1988) ohledně pozitivního vztahu mezi zadlužeností a likviditou společností. Podle všech těchto studií je však účinek likvidity pozitivní pouze tehdy, nemají-li manažeři žádnou rozhodovací pravomoc ohledně odprodeje aktiv, což snižuje riziko vyvlastnění majetku. Sibilkov (2007) zjistil, že likvidita zvyšuje náklady manažerského rozhodování a že vliv likvidity aktiv na pákový efekt je podmíněn kombinací zajištěných pohledávek a přímým vztahem mezi účinkem likvidity na nezajištěný dluh. Potvrdil také, že likvidita roste s růstem zadluženosti u vysoce zadlužených firem a firem s nízkým úrokovým krytím a u firem s nízkou hodnotou dlouhodobého majetku, resp. stálých aktiv k hodnotě nesplaceného dluhu.

Rovněž je potřeba si uvědomit, že vyšší likvidita snižuje očekávané náklady finanční tísně u věřitelů a tím umožňuje firmám vyšší zadluženost ex-ante a zvyšuje optimální množství dluhu. Tento pozitivní vztah je v souladu s některými trade off modely kapitálové struktury. Harris a Raviv (1990) tvrdí, že při výběru vhodné úrovně dluhu hledají investoři kompromis mezi současnou situací a budoucí očekávanou situací za podmínek zlepšení efektivnosti fungování provozní činnosti společností. Likvidita a efektivnost jsou tedy porovnávány s přínosy dluhového financování. Kromě toho Anderson (2002) tvrdí, že podniky s vysoce likvidními aktivy preferují vyšší míru zadlužení bez změny majetkové struktury. Potvrdil také negativní vztah mezi krátkodobou výpomocí a likviditou v prŕípadě, že prrichází v době, kdy má firma nedostatek hotovosti.

Pokud bychom shrnuli vnímání likvidity jednotlivými teoriemi, pak můžeme konstatovat, že z pozice kompromisní teorie se očekává pozitivní funkční vliv likvidity na využití cizích zdrojů financování. Myšlenka je podpořena především tím, že vyšší míra likvidity umožňuje získávání cizích zdrojů financování za lepších podmínek a pozitivně ta působí na pákový efekt. Naproti tomu teorie hierarchického pořádku vycházející z preference financování ze zadrženého a reinvestovaného zisku, dává růst likvidity do negativního funkčního vztahu s využitím cizích zdrojů financování. Vychází se však automaticky z předpokladu, že zisk je kryt $\mathrm{v}$ dostatečné míře finančními prostředky (vysokou likviditou) a tudíž není nutné pro investiční činnost podniku využívat jiné než vlastní zdroje financování. 
Existuje příčinná souvislost mezi likviditou a rentabilitou společnosti. Rentabilita i likvidita pozitivně ovlivní dostupnost cizích zdrojů financování. Avšak růst likvidity zpravidla může omezit efektivnost, nebot' likvidita předpokládá držení finančních prostředků v méně efektivní formě aktiv (zásoby, pohledávky, finanční majetek) $\mathrm{Z}$ hlediska rentability podniku kompromisní teorie říká, že ziskové podniky mají tendenci využít další cizí zdroje financování z důvodu existence a funkčnosti daňového štítu. Jsou-li podniky ziskové, pak za jinak nezměněných podmínek rostou jejich volné peněžní prostředky, klesá rizikovost z hlediska dostupnosti finančních prostředků obecně a zároveň roste dostupnost dluhového financování za výhodných podmínek z hlediska nákladů dluhu. Také to znamená, že s růstem ziskovosti klesá pravděpodobnost bankrotu a klesají náklady finanční tísně. Toto vede k podstatě tvrzení trade off teorií o pozitivním vztahu mezi rentabilitou vlastního kapitálu a využitým dluhovým financováním. Argumenty pro tato tvrzení je možné nalézt v celé řadě studií, např. Brealey, Myers (2000), Graham (2006) apod. Naproti tomu teorie hierarchického pořádku tvrdí, že při existenci interních zdrojů financování budou tyto preferovány v důsledku neexistence dodatečných transakčních nákladů. Cizí zdroje budou využity pouze při nedostatku nerozděleného zisku. S růstem ziskovosti roste snaha o zadržování zisku a nadbytek zadrženého zisku vede k nižší hodnotě dluhu. Dluh je zhlediska této teorie vnímán spíše jako signál nedostatečnosti z hlediska ziskovosti. V důsledku toho se očekává negativní vztah mezi ziskovostí a růstem využití cizích zdrojů financování. Argumenty pro tato tvrzení mohou být podložena studiemi Fama a Frenche (2002), Hovakimana et al. (2001), Beattie et al. (2006) apod.

\section{Metodologie a data}

Studie je zaměřena na oblast zpracovatelského průmyslu, nebot' toto odvětví má ve všech sledovaných zemích nejmenší podíl krachujících společností. Z odvětví zpracovatelského průmyslu byly získány údaje za jednotlivé podniky v kategorii velmi velké, velké a střední firmy $\mathrm{z}$ databáze Amadeus. Malé podniky byly z analýzy vyřazeny ze dvou důvodů. Prvním důvodem byla slabá dostupnost dat, nebot' dostupné časové řady vykazovaly značnou nedostatečnost $\mathrm{z}$ hlediska kontinuity, resp. doby existence společnosti. Druhým důvodem byla skutečnost, že primárním zájmem z hlediska řízení malých společností není korekce způsobů financování. Pozornost je většinou u těchto společností zaměřena na zajištění likvidní pozice a udržení se na trhu. Z vygenerovaného souboru byly odstraněny podniky, které nesplnily podmínku ucelené časové řady za léta 2006 až 2013, tzn. že nesměla v časové řadě chybět hodnota sledovaných položek za více než tři roky. Nastavení časové řady vycházelo $\mathrm{z}$ dostupnosti údajů $\mathrm{v}$ databázi. Zkoumaný vzorek na základě splnění těchto podmínek obsahuje v České republice 3483 podniků, v Mad'arsku 152, v Polsku 1263 a na Slovensku 345. Data jsou podkladem pro zpracování panelové regrese. Při konstrukci panelového regresního modelu budu vycházet ze studie Haas a Lelyveld (2010). Dostatečně široká datová základna $\mathrm{v}$ průřezu panely jednotlivých proměnných umožňuje užitím regresní metody náhodných momentů (GMM) dosáhnout robustních výsledků, a to i přes krátký sledovaný úsek. Prucha (2014) uvádí, že mnohá panelová data trpí problémem kratší časové řady a $\mathrm{z}$ hlediska panelové regrese užitím metody nejmenších čtverců na tempech růstu jsou tak zcela nevhodná k jejímu použití. Metoda náhodných momentů (Generalized Method of Moments, GMM) dle něj představuje způsob, jak zkoumat funkční vztahy právě mezi takovými panelovými daty. Finanční data na roční frekvenci, získána ze základních účetních výkazů, uspořádána $\mathrm{v}$ panelech, jsou $\mathrm{z}$ tohoto důvodu vhodným kandidátem pro výzkum užitím této regresní metody. Velkou výhodou užití GMM oproti metodě nejmenších čtverců je rovněž fakt, že mezi regresory také figuruje zpožděná endogenní, vysvětlovaná, závislá proměnná (Hall, 2005). Vztah bude obecně modelován rovnicí (1): 


$$
D E R_{i t}=\alpha_{1}+\beta_{1} * \Delta D E R_{i t-1}+\beta_{2} * X_{1 i t}+\beta_{3} * X_{2 i t}+\cdots \ldots \ldots \ldots+\beta_{n} * X_{\text {nit }}+\varepsilon_{i t}
$$

kde endogenní závisle proměnnou $D E R_{i t}$ bude ukazatel debt/equity ratio i-tého podniku v čase $\mathrm{t}$ hodnotící využití financování cizími zdroji, exogenními nezávisle proměnnými jsou zpožděná hodnota debt/equity ratio z předchozího roku $\Delta D E R_{i t-1}, X_{n i t}$ budou ostatní faktory, které mohou míru využití cizích zdrojů financování ovlivnit. K těmto faktorům bude patřit běžná likvidita (L3) a rentabilita vlastního kapitálu (ROE). Symboly $\alpha_{1}$ a $\varepsilon_{i t}$ jsou konstantou modelu a reziduální složkou v modelu GMM.

$\mathrm{Z}$ metodologického hlediska jsou použity především tři běžně užívané poměrové ukazatele. $\mathrm{D} / \mathrm{E}$ ratio hodnotí finanční strukturu společnosti. Využití tohoto ukazatele vychází ze studie Fisher, Heinkel a Zechner (1989). Do poměru vstupují cizí a vlastní zdroje financování využívané ve finančním hospodaření. Hodnoty vyšší než 1 signalizují větší využití cizích zdrojů financování, hodnoty nižší než jedna pak větší využití vlastních zdrojů. Dalším použitým ukazatelem je ukazatel běžné likvidity. Likvidita je důležitá z hlediska finanční rovnováhy firmy, nebot' jen dostatečně likvidní podnik je schopen dostát svým závazkủm. $\mathrm{Na}$ druhou stranu př́liš vysoká míra likvidity je nepříznivým jevem pro vlastníky podniku, nebot' finanční prostředky jsou vázány $\mathrm{v}$ aktivech, které nepracují ve prospěch výrazného zhodnocování finančních prostředků a „ukrajují“ tak z rentability. Je tedy potřeba hledat pokud možno vyváženou likviditu, která zaručí jak dostatečné zhodnocení prostředků, tak i schopnost dostát svým závazkům. Zároveň jde o ukazatel, který je rozhodný z hlediska ceny poskytnutých peněžních prostředků. Nízká úroveň likvidity vede ke zvýšení rizikovosti firmy při návratnosti peněžních prostředků věřitelům, což se promítne do úroku. Posledním ukazatelem, na který bude zaměřena analýza, je ROE (rentabilita vlastního kapitálu). Rozhodnutí o použití právě ROE vychází z faktu, že je to ukazatel, který je významně ovlivňován poměrem mezi využitými cizími a vlastními zdroji. Pro ostatní ukazatele je kapitálová struktura irelevantní. Rentabilita vlastního kapitálu (return on equity - ROE) se využívá pro hodnocení efektivního nakládání s prostředky vlastníků podniků. Ukazatel je konstruován jako podíl čistého zisku (EAT) podniku s hodnotou vlastního kapitálu. ROE obecně je považováno za jeden $\mathrm{z}$ nejdůležitějších ukazatelů hodnocení efektivnosti. Rentabilita vlastního kapitálu je zařazena jako nezávislá proměnná, nebot' při získávání zdrojů financování z bankovního sektoru hraje roli z hlediska stanovení ceny úvěru. Cena úvěru je pak i rozhodujícím faktorem o konečném rozhodnutí o využití nebo nevyužití úvěrového financování.

Cílem článku je zjistit, zda existuje pozitivní funkční vztah mezi nezávislými veličinami (likviditou a rentabilitou) a závislou veličinou (využitím cizích zdrojů financování) v podnicích ve zpracovatelském průmyslu v zemích Visegradské čtyřky v letech 2006 až 2013. Dá se předpokládat, že stabilita společností, tedy zajištění dostatečné likvidní pozice a rostoucí rentability, povede k většímu využívání cizích zdrojů financování. Rentabilita bude v tomto článku vnímána jako pomocná proměnná, důraz bude kladen na oblast platební schopnosti, nebot' ta primárně umožní zachování dlouhodobé existence podniku i vzhledem $\mathrm{k}$ celkové situaci $\mathrm{z}$ hlediska platební schopnosti v Evropě (viz níže). V návaznosti na výše uvedené studie a formulovaný cíl lze v rámci výzkumu vyjít ze dvou základních hypotéz.

H1: S rostoucí likviditou společnosti roste využití cizích zdrojů financování.

H2: S rostoucí rentabilitou společností roste využití cizích zdrojů financování.

Formulace hypotéz vychází z výsledků trade off teorií a budou verifikovány či falzifikovány na vzorku společností v každé z analyzovaných zemí. 


\section{Situace z hlediska platební schopnosti v Evropě}

Lze rríci, že vývoj platební neschopnosti podniků v Evropě reflektuje vývoj ekonomik po letech krize. Z tabulky č. 1 je patrné, že po období stagnace v letech 2010/2011 přišla nová vlna bankrotů. V západní Evropě jako celku v posledním sledovaném mezidobí narostl počet bankrotujících firem o $1,15 \%$. Nejhorší vývoj v tomto ohledu zaznamenává již léta Francie, kde je v posledních pěti letech evidován největší počet bankrotujících společností. Avšak z hlediska intenzity nárůstu počtu bankrotů mezi lety 2012/2013 byla situace nejhorší v Norsku, Itálii a Španělsku.

Tabulka 1: Vývoj počtu podniků v insolvenci mezi lety 2009 až 2013 v Evropě

\begin{tabular}{|l|c|c|c|c|c|}
\hline & 2009 & 2010 & 2011 & 2012 & 2013 \\
\hline Západní Evropa & 178235 & 174463 & 174183 & 190161 & 192340 \\
\hline CEE & n/a & 53351 & 69895 & 97169 & 100984 \\
\hline
\end{tabular}

Zdroj: Creditreform (2014)

Zaměříme-li pozornost na střední a východní Evropu (CEE), pak na tomto území bylo v roce 2013 zaznamenáno 100984 bankrotů, což oproti roku 2012 představuje nárůst o 3,5\%. K největšímu meziročnímu nárůstu došlo v Bulharsku (243,3 \%), v Chorvatsku $(174,2 \%)$ a ve Slovinsku (39,2\%). Budeme-li však vyjadřovat podíl bankrotujících firem na celkovém počtu ekonomicky aktivních firem, pak lze největší relativní podíl zaznamenat v Srbsku (7,93 \%), Rumunsku $(5,67 \%)$ a Mad'arsku (3,84 \%). Česká republika zaznamenala meziroční nárůst o 26,7 \% (7 142 bankrotujících firem v roce 2012), v relativním vyjádření na počtu ekonomicky aktivních společností to znamená 0,47 \%. Při posuzování výkonnosti jednotlivých ekonomických odvětví můžeme dospět k následujícím výsledkům, které jsou vyjádřeny $\mathrm{v}$ grafu č. 1 .

Obrázek 1: Rozložení insolventních podniků do klíčových oborů podnikání v západní a střední a východní Evropě

\begin{tabular}{|c|c|c|c|c|c|}
\hline & — Zpracovatelský průmysl & - Stavebnictví & - Obchod & \multicolumn{2}{|l|}{ - Služby } \\
\hline $32,70 \%$ & $37,20 \%$ & & $35,90 \%$ & & $37,20 \%$ \\
\hline $40,40 \%$ & $31,60 \%$ & & $32,40 \%$ & & $31,60 \%$ \\
\hline $14,40 \%$ & $14,60 \%$ & & $20,80 \%$ & & $21,30 \%$ \\
\hline $12,50 \%$ & $11,80 \%$ & & $10,90 \%$ & & $9,90 \%$ \\
\hline 2013 & 2012 & & 2013 & & 2012 \\
\hline \multicolumn{2}{|c|}{ STŘEDNÍ A VÝCHODNÍ EVROPA } & & \multicolumn{3}{|c|}{ ZÁPADNÍ EVROPA } \\
\hline
\end{tabular}

Zdroj: Creditreform (2014)

Z obrázku 1 je zřejmé, že v západní Evropě je rozložení firem s insolvencí přikloněno v oborové struktuře do oblasti terciálního sektoru, tedy na oblast obchodu a služeb. V těchto dvou sektorech zaznamenáváme v obou sledovaných letech více než $60 \%$ insolvenčních firem. Zhoršující se situaci můžeme zaznamenat v oblasti obchodu, která v sobě zahrnuje i oblast pohostinství a ubytovacích služeb. Podobnou situaci můžeme zaznamenat také ve střední a východní Evropě. Zde však v terciálním sektoru registrujeme ještě větší podíl firem v insolvenčním řízení, nebot' v letech 2012 a 2013 je tento podíl více než 70 \%. Naopak nejmenší podíl podniků s problematickou likviditou můžeme nalézt ve zpracovatelském průmyslu a to $\mathrm{i}$ přesto, že toto odvětví patří $\mathrm{v}$ celé Evropě $\mathrm{k}$ druhému nejpočetněji 
zastoupenému odvětví. Právě nejnižší podíl podniků v insolvenčním řízení vedl k rozhodnutí zabývat se právě tímto odvětvím. Z výše uvedených studií a souvislostí mezi rentabilitou, likviditou a využitými zdroji financování právě podniky, které nemají problémy se zajištěním likvidity, se mohou zabývat i využíváním cizích zdrojů financování pro podporu efektivního fungování podniku, což je také důvod, proč se další části studie zabývají právě oblastí zpracovatelského průmyslu. Ostatní oblasti průmyslu budou součástí dalších studií.

\section{Analýza funkčního vztahu průmyslového odvětví zpracovatelského průmyslu v zemích V4}

Ukazatele by podle teorií a výše uvedených studií měly vykazovat vzájemnou závislost. Jedním ze způsobů, jak tuto závislost měřit, je pomocí korelačního koeficientu. Využití korelačního koeficientu sice naznačí směr závislosti, ale nenaznačí kauzalitu posuzovaných proměnných. Korelace je vyjádřena pomocí následující rovnice (2).

$$
k_{X Y}=\frac{\operatorname{cov}(X, Y)}{\sigma_{X} \sigma_{Y}}
$$

kde $\mathrm{X}$ je střední hodnota matice hodnot debt/equity ratio a $\mathrm{Y}$ je střední hodnota matice hodnot rentability vlastního kapitálu či likvidity vždy vjednotlivých zemích. Hodnoty tohoto ukazatele by se měly pohybovat v intervalu od -1 do 1 . Hodnoty bližší hodnotě 1 by pak naznačovaly, že s růstem využití cizích zdrojů roste rentabilita vlastního kapitálu či likvidita společnosti a opačně. Hodnoty rovny nule signalizují vzájemnou nezávislost. Následující obrázek 2 vyjadřuje míru vzájemné závislosti sledovaných veličin v jednotlivých zemích.

Obrázek 2: Korelace vybraných veličin ve vztahu $\mathrm{k}$ D/E ratio v jednotlivých zemích za období 2006 až 2013

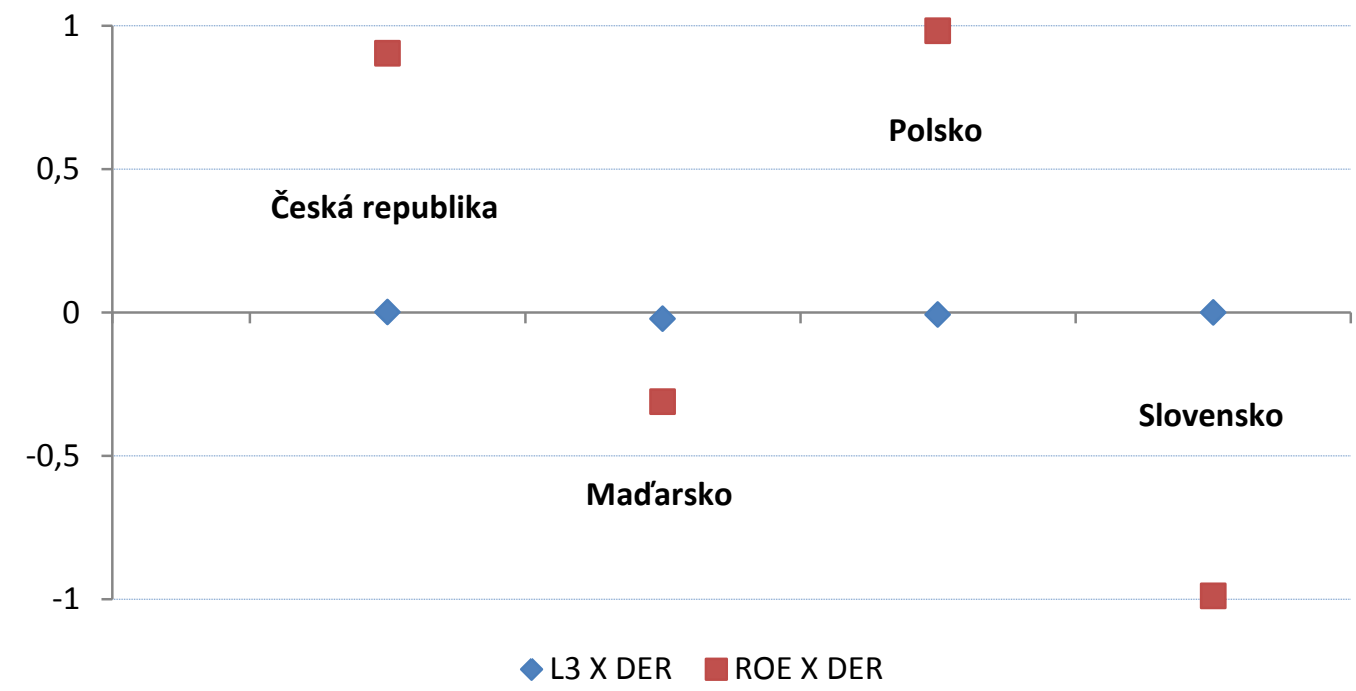

Zdroj: vlastní dle analýz podniků v jednotlivých zemích

Ve vzorku společností ve všech sledovaných zemích vychází vztah využití cizích zdrojů financování (DER) a likvidity jako nekorelovaný, resp. jako téměř nekorelovaný. Z hlediska potvrzení či vyvrácení hypotézy H1 je možné konstatovat, že hypotézu nebylo možné potvrdit, nebot' pozitivní vazba u korelace zaznamenána jen v ČR a je velmi slabá. U všech ostatních zemí vyšla korelace záporná, velmi blízká nulové hodnotě. Takže ani u ostatních zemí nelze hypotézu H1 potvrdit. Z hlediska vztahu DER a ROE je možné konstatovat, že s rostoucí rentabilitou roste využití cizích zdrojů financování v př́ípadě České republiky a 
Polska. Opačnou situaci sledujeme u Mad'arska a Slovenska, kde růst rentability znamená menší využití cizích zdrojů financování. To může souviset se snahou zadržovat generovaný zisk a jeho reinvestici v podnicích. Hypotéza $\mathrm{H} 2$ tak může být v rámci korelační analýzy potvrzena pro Českou republiku a Polsko a zamítnuta pro Mad'arsko a Slovensko.

Při použití GMM modelu ve vzorku společností, tak jak byl vymezen v úvodu tohoto článku, byla pozornost zaměřena na to, jak je vývoj použití cizích zdrojů financování (DER) ovlivněn dosahovanou likviditou, efektivností a využitím cizích zdrojů v předchozím období. Důvodem pro využití GMM modelu po korelační analýze je snaha o jasné vymezení závislých a nezávislých veličin. To nebylo $v$ rámci korelační analýzy možné. Vztah je vyjádřen následující rovnicí (3):

$$
D E R_{i t}=\alpha_{1}+\beta_{1} * \Delta D E R_{i t-1}+\beta_{2} * L 3_{i t}+\beta_{3} * R O E+\varepsilon_{i t}
$$

kde endogenní závisle proměnná $D E R_{i t}$ představuje využití cizích zdrojů financování i-tého podniku $\mathrm{v}$ čase $\mathrm{t}$, exogenními nezávisle proměnnými jsou zpožděná hodnota DER z předchozího roku $\triangle D E R_{i t-1}$, vývoj likvidity $L 3_{i t}$ a vývoj rentability vlastního kapitálu $R O E$. Symboly $\alpha_{1}$ a $\varepsilon_{i t}$ jsou konstantou modelu a reziduální složkou v modelu GMM. Situace je postupně modelována na vzorku společností ze zemí Visegradské čtyřky. Tabulka 2 dokumentuje situaci v podmínkách České republiky, kde je do vzorku ze zpracovatelského průmyslu zahrnuto 3483 podniků.

Tabulka 2: Debt/equity ratio jako závislá veličina v České republice

\begin{tabular}{|c|r|r|r|r|}
\hline Variable & Coefficient & Std. Error & t-Statistic & Prob. \\
\hline DER(-1) & -0.003419 & 0.001584 & -2.159029 & 0.0309 \\
\hline L3 & 0.000155 & $3.39 \mathrm{E}-05$ & 4.588712 & 0.0000 \\
\hline ROE & 32.86009 & 1.429264 & 22.99092 & 0.0000 \\
\hline \multicolumn{5}{|c|}{ Effects Specification } \\
\hline Cross-section fixed (orthogonal deviations) & 671.1097 \\
\hline Mean dependent var & 1.301543 & S.D. dependent var & $1.44 \mathrm{E}+09$ \\
\hline S.E. of regression & 267.3280 & Sum squared resid & 23 \\
\hline J-statistic & 18.84226 & Instrument rank & \\
\hline
\end{tabular}

Zdroj: vlastní dle analýz podniků $\mathrm{v}$ jednotlivých zemích

Z tabulky 2 je patrné, že analyzovaný vzorek společností vykazuje pozitivní vztah jak v kontextu rentability, tak i v kontextu likvidity. Je také patrné, že vazba využití cizích zdrojů financování a likvidity je výrazně slabší, ačkoliv obě nezávislé veličiny vykazují ve vztahu stejnou statistickou významnost. Z modelu také vyplývá, že s rostoucí rentabilitou roste i využití cizích zdrojů financování a větší využití cizích zdrojů je do určité míry spojeno také s posílením likvidní pozice podniků. Opačnou tendenci můžeme zaznamenat při předchozím využití cizích zdrojů financování. Ve své podstatě to znamená, že za sledované období podniky ve zpracovatelském průmyslu mají tendenci méně využívat cizí zdroje financování, pokud je ve větší míře využívaly v předchozím roce. Zároveň také platí, že pokud rostla rentabilita a posílila likvidní pozice podniků, rostlo využití cizích zdrojů financování. Z hlediska formulovaných hypotéz můžeme konstatovat, že se vČeské republice obě hypotézy potvrdily, i když je pozitivní vazba u L3 je velmi slabá. Tabulka 3 dokumentuje situaci v Polsku, které vykázalo druhý největší vzorek - 1263 podniků. 
Tabulka 3: Debt/equity ratio jako závislá veličina v Polsku

\begin{tabular}{|c|r|r|r|r|}
\hline Variable & Coefficient & Std. Error & t-Statistic & Prob. \\
\hline DER(-1) & -0.157527 & 0.004166 & -37.81242 & 0.0000 \\
\hline L3 & -0.027346 & 0.021163 & -1.292182 & 0.1963 \\
\hline ROE & 4.807496 & 0.002294 & 2096.015 & 0.0000 \\
\hline \multicolumn{5}{|c|}{ Effects Specification } \\
\hline Cross-section fixed (orthogonal deviations) & 365.3110 \\
\hline Mean dependent var & -9.309408 & S.D. dependent var & 26368700 \\
\hline S.E. of regression & 64.63910 & Sum squared resid & 23 \\
\hline J-statistic & 27.00696 & Instrument rank & \\
\hline
\end{tabular}

Zdroj: vlastní dle analýz podniků v jednotlivých zemích

Statisticky významnou vazbu v polských společnostech zpracovatelského průmyslu mají pouze využití cizích zdrojů v předchozím období a rentabilita vlastního kapitálu. Rentabilita je spojena s pozitivní funkční závislostí. V praxi to tedy znamená, že pokud je hospodaření společností podpořeno rostoucí rentabilitou, využívají společnosti ve větší míře cizí zdroje financování. Naopak využití cizích zdrojů financování v předchozím roce vykazuje negativní funkční závislost. To lze interpretovat tak, že jsou-li v předchozím období ve větší míře využity cizí zdroje financování, pak v následujícím období využití cizích zdrojů financování klesá. Rozhodnutí o hypotézách není v případě Polska tak jednoznačné, jako tomu bylo u České republiky. U rentability je možné hypotézu H2 potvrdit, avšak u likvidity je potřeba ji zamítnout z pozice dosahované negativní vazby. Analýza pomocí GMM modelu v polských společnostech zpracovatelského průmyslu v tabulce 3 naznačila vzhledem k nulové hypotéze, že výsledky nejsou statisticky významné. Likvidita má negativní funkční závislost, ale zároveň je možné říci, že to nelze jednoznačně zobecnit, nebot' výsledky se ukazují jako statisticky nevýznamné. Další dvě analyzované země už mají vzorek společností výrazně menší. Obzvláště problematické je získávání dat z Mad'arska, odkud byly v databázi Amadeus získány informace od 152 společností. Tabulka 4 naznačuje výsledky získané v Mad'arsku.

Tabulka 4: Debt/equity ratio jako závislá veličina v Mad’arsku

\begin{tabular}{|l|r|r|r|r|}
\hline Variable & Coefficient & Std. Error & t-Statistic & Prob. \\
\hline DER(-1) & -0.054237 & 0.001327 & -40.87030 & 0.0000 \\
\hline L3 & -0.227379 & 0.130517 & -1.742138 & 0.0820 \\
\hline ROE & -0.579398 & 0.241498 & -2.399188 & 0.0167 \\
\hline \multicolumn{5}{|c|}{ Effects Specification } \\
\hline Cross-section fixed (orthogonal deviations) & 39.68944 \\
\hline S.E. of regression & 0.940331 & S.D. dependent var & 1154176. \\
\hline J-statistic & 42.93869 & Sum squared resid & 23 \\
\hline
\end{tabular}

Zdroj: vlastní dle analýz podniků v jednotlivých zemích

Z tabulky č. 4 vyplývá, že všechny sledované nezávislé veličiny vykazují negativní funkční vazbu s různou statistickou významností. U rentability je vykázána negativní funkční závislost, která naznačuje, že růst rentability vyvolá menší využívání cizích zdrojů financování. Dalo by se tedy vyvozovat, že podniky mají tendenci ve větší míře reinvestovat generovaný zisk a v menší míře je rozdělovat mezi vlastníky společností. Pro rentabilitu je možné hypotézu zamítnout, protože nevykázala pozitivní funkční závislost. Pro likviditu můžeme konstatovat, že s růstem likvidity klesá využití cizích zdrojů financování, což naznačuje, že cizí zdroje financování jsou využívány především ke krytí finanční nedostatečnosti podniků. Navíc je však možné z hlediska modelu říct, že je tento výsledek statisticky významný až na hladině $10 \%$, což mírně snižuje vypovídací schopnost tohoto výsledku. O hypotéze z hlediska likvidity nelze tedy jednoznačně rozhodnout, nebot' výsledky 
neumožňují zobecnění závěrů. Nicméně toto konstatování je možné podpořit také informací společnosti Creditreform, s.r.o., podle níž patří Mad'arsko spolu s Rumunskem k zemím s největším počtem bankrotů (Creditreform, 2014). To také podporuje výsledek z rentability vlastního kapitálu. Poslední vzorek slovenských podniků ve zpracovatelském průmyslu obsahuje 345 firem.

Tabulka 5: Debt/equity ratio jako závislá veličina na Slovensku

\begin{tabular}{|c|r|r|r|r|}
\hline Variable & Coefficient & Std. Error & t-Statistic & Prob. \\
\hline DER(-1) & -0.001564 & $4.59 E-05$ & -34.07833 & 0.0000 \\
\hline L3 & -0.001236 & 0.000454 & -2.721357 & 0.0066 \\
\hline ROE & -17.50053 & 0.084872 & -206.1993 & 0.0000 \\
\hline \multicolumn{5}{|c|}{ Effects Specification } \\
\hline Cross-section fixed (orthogonal deviations) & 321.4540 \\
\hline S.E. of regression & -6.457197 & S.D. dependent var & 3051644. \\
\hline J-statistic & 39.48858 & Sum squared resid & 23 \\
\hline
\end{tabular}

Zdroj: vlastní dle analýz podniků v jednotlivých zemích

Z hlediska funkční závislosti dopadl vztah závislé veličiny s veličinami nezávislými stejně jako u analyzovaného mad'arského vzorku. U všech nezávislých veličin sledujeme negativní funkční vztah. Odlišností je pouze skutečnost, že u všech sledovaných veličin jsou výsledky statisticky významné na hladině $1 \%$, což signalizuje velmi dobrou vypovídací schopnost vzhledem ke zobecnění argumentů. Ovšem vliv likvidity i využití cizích zdrojů financování v předchozím období je velmi slabý, což znamená, že obě tyto veličiny ovlivní rozhodování o využití cizích zdrojů financování zřejmě okrajově. Silnou funkční závislost můžeme nalézt při vlivu rentability na využití cizích zdrojů financování. Zde platí stejný vztah jako u Mad'arska, to znamená, že růst rentability vyvolá menší využití cizích zdrojů financování. I zde se tedy můžeme domnívat, že společnosti mají větší tendenci zisk zadržovat a reinvestovat je $v$ rámci podnikatelské činnosti. I na Slovensku platí, že ani jednu z formulovaných hypotéz nelze potvrdit, nebot' funkční vztah vykázal negativní závislost.

\section{Závěr}

Cílem článku bylo zjistit, zda existuje pozitivní funkční vztah mezi nezávislými veličinami (likviditou a rentabilitou) a závislou veličinou (využitím cizích zdrojů financování) v podnicích ve zpracovatelském průmyslu v zemích Visegradské čtyřky v letech 2006 až 2013. Očekávání pozitivního funkčního vztahu vycházelo z již dřive realizovaných studií a také z předpokladu, že stabilizovaná finanční situace podniku povede k většímu využívání cizích zdrojů financování. Formulovány byly rovněž dvě hypotézy, které měly potvrdit nebo vyvrátit očekávání. Výsledky korelační analýzy a modelu GMM shrnuje tabulka č. 6 .

Tabulka 6: Vlivy jednotlivých veličin na využití cizích zdrojů financování podle způsobů zkoumání

\begin{tabular}{|l|c|c|c|c|c|c|c|}
\hline & \multicolumn{2}{|c|}{ Očekávání } & \multicolumn{2}{c|}{ Vliv korelace } & \multicolumn{3}{c|}{ Vliv v modelu GMM } \\
\cline { 4 - 8 } & L3 & ROE & L3 & ROE & $\Delta$ DER & L3 & ROE \\
\hline \multirow{3}{*}{ Česká republika } & \multirow{3}{*}{+} & \multirow{3}{*}{+} & + & + & - & + & + \\
\hline Mad'arsko & \multirow{2}{*}{+} & - & - & - & - & - \\
\hline Polsko & & - & + & - & - & + \\
\hline Slovensko & & - & - & - & - & - \\
\hline
\end{tabular}

Zdroj: vlastní dle provedených analýz

Z tabulky vyplývá, že situace není zcela jednoznačná a existují rozdíly v jednotlivých zemích i z hlediska použité metodologie zkoumání. V rámci korelační analýzy se očekávání v plné 
míře potvrdilo pouze v podmínkách České republiky, avšak hladina významnosti u likvidity je nad úrovní $10 \%$, takže jednoznačné zobecnění není v tomto ohledu možné. U ostatních sledovaných zemí byl zaznamenán negativní funkční vliv mezi likviditou a využitím cizích zdrojů financování, což by znamenalo, že ani stabilizovaná situace z hlediska platební schopnosti podniků nevede k větší míre využití cizích zdrojů financování. Však podobně jako u České republiky také výsledky korelační analýzy v Mad'arsku, Polsku a na Slovensku se pohybovaly na úrovni statisticky nevýznamných položek, nebot' u všech analyzovaných zemí byla hladina významnosti vyšší než $10 \%$. Právě z důvodu statistické nevýznamnosti byl pro analýzu využit ještě další metodologický př́stup. V rámci modelu GMM bylo možné jako položku s nízkou, resp. nižší hladinou významnosti označit pouze funkční vztah mezi likviditou a využitými cizími zdroji financování. U rentability vlastního kapitálu však funkční závislost nevyšla ve všech sledovaných zemích stejně, jako tomu bylo u korelace, ale Česká republika a Polsko vykázaly pozitivní funkční závislost a Mad’arsko a Slovensko vykázaly negativní funkční závislost. Očekávání se tedy v plné míře naplnily jen u České republiky, kde jak likvidita, tak i rentabilita vykázaly pozitivní vliv na větší využití cizích zdrojů financování. Zcela se nenaplnila očekávání v Mad’arsku a na Slovensku, nebot' zde při růstu likvidity a růstu rentability klesala míra využití cizích zdrojů financování. Je možné tedy konstatovat, že hypotéza 1 , že s rostoucí likviditou společnosti roste využití cizích zdrojů financování, byla verifikována pouze v České republice a to jak za použití korelační analýzy, tak při použití GMM modelu. V ostatních sledovaných zemích musíme tuto hypotézu zamítnout. Druhá hypotéza, že s rostoucí rentabilitou společností roste využití cizích zdrojů financování, je v plné přijímána pouze u korelační analýzy ve všech sledovaných zemích. V modelu GMM je možné ji verifikovat pouze v České republice a Polsku, pro Slovensko a Mad'arsko musí být v modelu GMM hypotéza zamítnuta. V tomto ohledu se nabízejí nové výzkumné otázky, například, které faktory ovlivní rozhodnutí podniků využít větší množství cizích zdrojů financování, do jaké míry se menší využití cizích zdrojů financování projevuje do zadržování a nerozdělování generovaného zisku.

\section{Literatura}

[1] ANDERSON, R. W., 2002. Capital structure, firm liquidity and growth [online]. [vid. 2013-04-29]. Dostupné z: www.nbb.be/doc/ts/publications/wp/WP27en.pdf

[2] BEATTIE, V. et al., 2006. Corporate financing decisions: UK survey evidence. Journal of Business Finance and Accounting, 33(9-10), 1402-1434. ISSN 1468-5957.

[3] BREALEY, R. a S. C. MYERS, 2000. Principles of Corporate Finance. New York: McGraw-Hill, 6. vydání. ISBN 0-07-709565-0.

[4] FAMA, E. F. a K. R. FRENCH, 2002. Testing Trade-Off and Pecking Order Predictions About Dividends and Debt. Review of Financial Studies, 15(1), 1-33. ISSN 1465-7368.

[5] FISCHER, E. O., R. HEINKEL a J. ZECHNER, 1989. Dynamic Capital Structure Choice: Theory and Tests. The Journal of Finance, 44(1), 19-40. ISSN 1540-6261.

[6] GRAHAM, J. R., 2006. A review of taxes and corporate finance. Foundations and Trends in Finance [online]. 1(7), 573-691 [vid. 2013-09-18] Dostupné z: dx.doi.org $/ 10.1561 / 0500000010$

[7] HAAS, R. a I. LELYVELD, 2010. Internal capital markets and lending by multinational bank subsidiaries. Journal of Financial Intermediation [online]. 19, 1-25 [vid. 2013-0918]. Dostupné Z: www.sciencedirect.com/science/article/B6WJD-4VJ07JK1/2/49949562160fbe5ed0a1dae3c3f1ee93 
[8] HALL, A. R., 2005. Generalized Method of Moments (Advanced Texts in Econometrics). Oxford: University Press. ISBN 0-19-877521-0.

[9] HARRIS, M. a A. RAVIV, 1991. The Theory of Capital Structure. The Journal of finance, 46(1), 297-355. ISSN 1540-6261.

[10] HOVAKIMIAN, A., T. OPLER a S. TITMAN, 2001. The Debt-equity choice. Journal of Financial and Quantitative Analysis, 36, 1-24. ISSN 1756-6916.

[11] KIM, CH., D. C. MAUER a A. E. SHERMAN, 1998. The Determinants of Corporate Liquidity: Theory and Evidence. The Journal of Financial and Quantitative Analysis [online]. 33(3), 335-359 [vid. 2013-09-18]. Dostupné z: www.jstor.org/ discover $/ 10.2307 / 2331099$ ?uid=3737856\&uid=2129\&uid=2\&uid=70\&uid=4\&sid=2110 2805242313

[12] MORELLEC, E., 2001. Asset liquidity, capital structure, and secured debt. Journal of Financial Economics, 61(2), 173-206. ISSN 0304-405X.

[13] MYERS, S. C. a R. G. RAJAN, 1998. The Paradox Of Liquidity. The Quarterly Journal of Economics, MIT Press, 113(3), 733-771. ISSN 1531-4650.

[14] OPLER, T., L. PINKOWITZ, R. STULZ a R. WILLIAMSON, 1999. The Determinants and Implications of Corporate Cash Holdings [online]. [vid. 2013-09-18]. Dostupné $\quad z$ : $\quad$ www.sciencedirect.com/science/article/B6VBX-3WG358W1/2/98c97a1cf2d119d5228aca62948cb475

[15] PRUCHA, I. R., 2014. Instrumental Variables/Method of Moments Estimation. In: M. M. FISHER and P. NIJKAMP, eds. Handbook of Regional Science. Heidelberg: Springer. ISBN 978-3-642-23430-9.

[16] SHLEIFER, A. a R. W. VISHNY, 2001. Stock Market Driven Acquisitions. Journal of Financial Economics [online]. December 2001 [vid.2013-09-18]. Dostupné z: papers. ssrn.com/sol3/papers.cfm?abstract_id=278563

[17] SIBILKOV, V., 2007. Asset liquidity and capital structure [online]. [vid. 2013-04-29] Dostupné z: pantherfile.uwm.edu/sibilkov/www/liquidity.pdf

[18] WILLIAMSON, O. E., 1988. Corporate Finance and Corporate Governance. Journal of Finance, 43(3), 567-591. ISSN 1540-6261.

[19] Corporate insolvencies in Europe. Creditreform 2013/2014 [online]. [vid. 2015-08-29]. Dostupné $\quad$ z: www.creditreform.de/fileadmin/user_upload/crefo/download_de/news_ termine/wirtschaftsforschung/insolvenzen-europa/Analysis_Corporate_insolvencies_in_ Europe_2013-14.pdf 